\title{
Contra Externalisation: Analogies between Anarchism and Mysticism
}

Stefan Rossbach

University of Kent, UK

In her classic work The Silent Cry, Dorothee Sölle referred to mysticism as "the antiauthoritarian religion per se" (Sölle 200I: 36), suggesting an analogy between mysticism and anarchism. In this essay we explore this analogy by first discussing the mystical experience as a 'stepping out', as ekstasis, whereby the 'I' leaves itself as the being defined by the commotion of the world, achieving an at-one-ment with itself. The 'stepping out' of the mystic enables a mode of being marked by being 'present in relation', which contrasts sharply with the practices of 'externalisation' that outsource agency and surrender self-direction. Drawing on Plato's critique of politics in the Republic, we identify 'externalisation' as the very essence of political life. Among modern philosophers, Roussean is the foremost analyst of 'externalisation', and he provides the link to the radical reformers and anarchists who followed him. It is thus in the rejection of 'externalisation' that mysticism and anarchism converge, and accordingly we suggest that they occupy analogous positions within their respective fields of political theory and theology. How these ideas work together is most clearly illustrated in the life and work of Gustav Landaner, whose encounter with Meister Eckhart's sermons was formative for his mystic anarchism and the concomitant rejection of politics as encrusted 'externalisation'. The parallel discussion of mysticism and anarchism shows that, even if articulated in secular or even atheist terms, and to the extent that it advocates the overcoming of externalising practices, anarchism has at its core a spiritual concern.

How to cite this book chapter:

Rossbach, S. 2020. Contra Externalisation: Analogies between Anarchism and Mysticism. In: Christoyannopoulos, A. and Adams, M. S. (eds.) Essays in Anarchism and Religion: Volume III. Pp. 223-254. Stockholm: Stockholm University Press. DOI: https://doi.org/Io.I6993/bbb.g. License: CC-BY 


\section{Introduction and overview}

In her I 997 book The Silent Cry, Dorothee Sölle (I929-2003) suggested that there was a strong analogy between mysticism and resistance. Mysticism heralds the possibility of a personal revelation outside the conventional canon of scripture and independently of clergical approval. The self-understanding of the mystics and their sense of purpose do not derive from the authority of a book, dogma, ritual or priest. The unmediated nearness to God proclaimed by mystics is a provocation to the existing institutions and intellectual authorities if their claim to power in society rests precisely on the idea of a privileged or indeed exclusive access to the divine. In the past, therefore, established institutions tended to look with suspicion at mystic visionaries and did not hesitate to collaborate with secular forces in order to oppress unorthodox teaching.

Because mysticism bypasses institutional authority, Sölle calls it "the antiauthoritarian religion per se" (Sölle 200I: 36), thereby suggesting an analogy not just between mysticism and resistance, but between mysticism and anarchism - and it is this latter analogy that we aim to explore further in this essay. We argue that there is a sense in which the role played by anarchism within political theory is analogous to the role played by mysticism within theology. In order to make this argument plausible, we begin in Section I. with a brief discussion of the mystical experience itself, which we understand as a 'stepping out', as ekstasis, which breaks through the commotion of the world and allows the mystic to experience a moment of 'pure presence'. After describing some of the key features of this experience, focusing on the Christian variants, we proceed to investigate its relationship to community. Contrary to the common view that "mysticism negates community" (Buber, see below), we argue that the mystical experience is the beginning of a new kind of relationality, of a mode of being marked by being 'present in relation'. Drawing on Plato's critique of 'politics' in the Republic, we argue in Section II. that this relationality contrasts sharply with the practices of 'externalisation' that define the very essence of political life. In Section III. we turn to anarchism and argue that 'externalisation' is indeed the primary target also of the anarchist critique. We support this argument with a discussion of the foremost modern theorist of 'externalisation', Jean-Jacques 
Rousseau, who during the $19^{\text {th }}$ century was widely considered the 'grandfather' of contemporary radical reformers. While it is true that anarchists such as Godwin and Proudhon found much to disagree with in Rousseau, their thinking did converge on two core positions, namely that (i) moral self-direction was the defining feature of human existence and that (ii) externalisation was the fabric of modern, civilised society, which thereby jeopardised our very humanity. We conclude that it is in their orientation away from externalisation that anarchism and mysticism establish themselves as analogous in their respective fields. A brief discussion of Gustav Landauer's 'mystic anarchism' allows us to provide an illustration of how the analogy unfolds within the life-work of an anarchist thinker and activist. While Landauer represents a 'perfect storm' within the cluster of ideas and concepts explored in this essay, it is important to underline that he is but an illustration - our argument is that the analogy between mysticism and anarchism holds at a deeper, theoretical level, so that it should be possible, in future research, to trace it in other anarchist thinkers as well. One of the interesting corollaries of this insight is that anarchism, regardless of whether it is presented in secular or even atheist terms, has at its core a spiritual concern.

\section{Mysticism}

Modern commentators are quick to emphasize that it is difficult to define 'mysticism' though all seem to agree that the term refers to a particular type of experience. In his classic definition, William James suggested that mystical experience was marked by "ineffability", "noetic quality" and "transience and passivity" (James I985: 379-382). William Ralph Inge finds in mysticism the "attempt to realise, in thought or in feeling, the immanence of the temporal in the eternal, and of the eternal in the temporal" (quoted in Ellwood I999: I6). Robert Ellwood defines the mystical experience as a religious experience that is "immediately or subsequently interpreted by the experiencer as a direct unmediated encounter with ultimate divine reality." This experience engenders a "deep sense of unity" and suggests that "during the experience the experiencer was living on a level of being other than the ordinary" (Ellwood I999: 39). 
Jerome Gellman describes a mystical experience as an experience in which a person "has a nonsensory perception apparently of a reality (or state of affairs) of a sort that can neither be perceived by sense perception nor known by ordinary introspective self-awareness" (Gellman 200I: 4). Sölle summarises that "a mystic is someone who has particular experiences that bring about altered states of consciousness deriving from the encounter with the other, the divine reality" (Sölle 200I: I6).

In the accounts of mystical experiences, the encounter with the Divine is commonly represented as a 'stepping out', as ecstasy - ekstasis. Coming into contact with the other, divine reality entails a stepping out of the limits of our common, everyday world. The mystic, however, is painfully aware that the ' $\mathrm{I}$ ' of the person undergoing the experience is included and indeed determined by this world, so that stepping out of the world entails a stepping out of the 'I', a losing of oneself. The 'I' leaves the everyday world and, at the same time, "leaves itself as the being defined by that world" (Sölle 200I: 27). Thereby, ekstasis becomes an expression of the "uttermost freedom from what determines our lives" (Sölle 200I: 27).

According to Eric Robertson Dodds, Plotinus was the first to use the term ekstasis in the context of mystical experience (Dodds I965: 72; Hadot I993: 32-33). In Plotinus's symbolism, the soul transcends being and becomes one with the "completely other" on the last stage of the mystical ascent. In union with the One, the soul "becomes itself and what it was; life in this world of sense being a falling away, an exile, 'a shedding of wings'” (VI, 9.9 as in Plotinus I969: 622-623; cf. Gregory I999: I 27), where Plotinus took the 'shedding of wings' expression from Plato's Phaedrus (248c). The soul experiences this movement, Plotinus explains, as a return to its origins, to the "land of its birth" where it is "nowhere deflected in its being", having attained "to solitude in untroubled stillness", "utterly at rest" (VI, 9.7, 9.9, 9.I I as in Potinus 1969: 620-62 I, 622-623, 624-625; cf. Gregory I999: I25, I28, I29). This is the "end of the journey" (VI, 9.I I as in Plotinus I969: 625; cf. Gregory I999: I30). Thus, as the soul finds itself in union with the One, it finds itself beyond being, completely outside itself this is the moment Plotinus calls ekstasis. 
In accordance with Plotinus's account, mystics talk about their experience not just as one of 'stepping out', of ekstasis and freedom, but also as an experience of being at one with themselves. The stepping out of the 'I' is a form of self-giving, a cessation of the ego as it was defined by the world, leading to the simultaneous discovery of a deeper, more real self. The implication is that in our normal lives we are very rarely wholly present in what we experience. We usually act and think only with a part of ourselves; we continue to watch ourselves and "do not attain the self-forgetfulness of being one" (Sölle 200I: 25). The freedom of mystical ekstasis is the freedom of being one, which allows us to act in fullness of our being. The stepping out, paradoxically, is thus also a self-discovery or indeed a restoration of self, which is free from fear to the extent that it enjoys a 'pure presence' - "nowhere deflected in its being”, to quote Plotinus again. Retrospectively, after the stepping out experience, mystics tend to look back to their previous lives as a fake, oppressed, and unreal existence, which did not involve their true selves. Through the mystical ekstasis, the mystic is 'made whole'.

Inspired by Joseph Marechal's Studies in the Psychology of the Mystics (1927), Bernard McGinn came to adopt the term 'presence' as the central notion for "grasping the unifying note in the varieties of Christian mysticism": "the mystical element in Christianity is that part of its belief and practices that concerns the preparation for, the consciousness of, and the reaction to what can be described as the immediate or direct presence of God" (McGinn I997: xvii). Christian believers, McGinn elaborates, affirmed that God can become present in ordinary religious observances as e.g. in prayer, sacrament and other rituals, but not in any "direct or immediate fashion" (McGinn I997: xviii). Mystical accounts, in contrast, attest to an immediate divine presence outside such observances. The presence referred to here, however, is always marked by duality and simultaneity, because while God is experienced as present, the one undergoing this experience will also be lifted to a new level of awareness, to a heightened and more intense consciousness involving the whole of his or her being. It is the simultaneity and coincidence of the two 'presences' that allows the mystic to experience divine presence as an interior phenomenon. 
It is not a paradox, therefore, for Martin Buber to note that mystical ekstasis is an inward experience. Ekstasis is both a process and a moment of differentiation whereby the true self differentiates itself vis-à-vis the commotion of the world. The commotion, Buber explained, was "only the outside of an unknown Inward which is the most living thing of all". The experience is beyond knowledge because "this Inward can withhold the experience of itself from knowledge, which is a daughter of the commotion, but not from the vibrant and self-liberating soul" (Buber I996: I):

But there is an experience which grows in the soul out of the soul itself, without contact and without restraint, in naked oneness. It comes into being and completes itself beyond the commotion, free of the other, inaccessible to the other. It needs no nourishment, and no poison can touch it. The soul which stands in it stands in itself, has itself, experiences itself - boundlessly. It experiences itself as a unity, no longer because it has surrendered itself wholly to a thing of the world, gather itself wholly in a thing of the world, but because it has submerged itself entirely in itself, has plunged down to the very ground of itself, is kernel and husk, sun and eye, carouser and drink, at once. This most inward of all experiences is what the Greeks call $e k$-stasis, a stepping out. (Buber I996: 2)

The mystical ecstasy is thus an experience of unity and oneness with oneself, which in turn realigns the self's relationship with the world and with the divine. As a manifestation of the humandivine encounter, the experience is acknowledged in a vast range of spiritual symbolisms and practices, from world religions such as Christianity and Islam to more local practices such as trance possession of the loa in Haitian voodoo. In non-theistic religions, mystical ecstasy is often presented as an illumination; in theistic religions, the encounter is a union of the soul and God - the unio mystica. Especially in Christian contexts, the 'stepping out' of the unio mystica is a precondition of, and simultaneous with, the 'entering into God', which is followed by being 'filled with God', enthusiasmos. The experience is differentiation and union at the same time, because, by entering into God and by being filled with God, "I am both more me and more than me" so that "the very contrast between union and differentiation is itself transcended, a condition in which the affirmation of the one is not bought at the price of the denial of the other." (Turner I995: 58). 
Mystics struggle to articulate their experience in language. As Buber explained, "[e]cstasy stands beyond common experience. It is unity, solitude, uniqueness: that which cannot be transferred. It is the abyss that cannot be fathomed: the unsayable." (Buber I996: 6) Sölle, too, notes that "nearly all mystics give voice to the problem of the inadequacy of language" (Sölle 200I: 56). Accordingly they draw on negation, paradox and silence as they attempt to communicate the process of their own transformation. Language, which dissects by naming, appears to interrupt or disturb the vision of unity; it introduces dualisms, dichotomies, binary distinctions in order to enable the speaker to 'intend' reality. To the extent that they succeed in negating, de-stabilising and avoiding such dichotomies, mystics speak an "anarchistic language" (Sölle 200I: 63) which is unable to name and hence to evoke relationships of domination.

That there is an intriguing and important relationship between mysticism and politics has not escaped the attention of commentators and, indeed, mystics. Not unlike Sölle, who characterises mysticism as 'anti-authoritarian', Evelyn Underhill speaks of a "mystic freedom which conditions, instead of being conditioned by, its normal world [...]" (Underhill 2002: 447). There is no 'structure', and certainly no structure of domination, that could prevent or contain the ecstasy of mysticism. Accordingly, those who stress the "inherent politics in all mysticism" (Fox I98 I: 54I) point to the potentially subversive nature of experiences and ways of life that transcend existing hierarchies, constraints and systems of oppression (Critchley 2009).

Yet, while the appreciation of mysticism as a form of resistance and critique - even as a form of deconstruction (Derrida I992a, I992b) - is surprisingly widespread, it is far less clear whether this form of critique can assume a political role not just by challenging existing power structures but also by informing alternative ways of life and the formation of alternative communities. Is the ekstasis of the mystic so radical that it implies a stepping out of community altogether? In an argument with Ernest Troeltsch at the First German Conference of Sociologists in October I9Io, Martin Buber rejected the idea that mysticism was a "sociological category" and insisted that mystical experience was a form of "religious solipsism": 
It also seems to me that mysticism negates community - mysticism does not struggle with any organized community, nor does it set itself up as a countercommunity, as a sect would. Rather mysticism negates community, precisely because for it there is only one real relation, the relation to God. The process noted by Professor Troeltsch, the coming together of the believers, [...] does not at all occur in mysticism. The [mystic] remains thoroughly isolated in his belief, for nothing else matters to him than to be alone with his God. (Buber quoted in Mendes-Flohr I996: xvii-xviii)

Buber would eventually replace the juxtaposition of ecstasy and worldly commotion with an elaboration of the "primary word" I-Thou (Buber I958). At the time he understood this change of perspective as a 'conversion' away from the 'exceptional' experience of mystical otherness to the 'need to be present' in everyday life:

Since then I have given up the 'religious' which is nothing but the exception, extraction, exaltation, ecstasy; or it has given me up. I possess nothing but the everyday out of which I am never taken. (Buber I967: 26)

However, calling this change in his outlook a 'conversion' is an exaggeration, especially as the conversion itself resulted from an experience, an encounter (Moore I996: xxi). The Thou is met through grace; it cannot be found by seeking (Buber I958: 24). When spoken, "the primary word I-Thou establishes the world of relation", which subsequently I "body forth", and "[i]n bodying forth I disclose. I lead the form across - into the world of It." Buber translates grace into relation: "all real living is meeting" (Buber I958: I 8, 23, 25). Ecstasy may be extra-ordinary, but its impact radiates into everydayness. Ecstasy is not a step into isolation but a shedding of the ties that bind us to the commotion of the world and hence a restoration of our ability to be open to, and hence to respond to, reality. The stepping out thereby becomes a new 'immersing in'.

The mystic is thus not a selfish visionary or an individual seeking to escape from the world, but someone who is again able to be open to reality and hence to be 'present in relation'. This process of restoration may entail a moment of individuation, but not in a sense that would hinder our ability to relate. On the contrary, 
by turning inwards we become more able to attune ourselves to one another. Becoming more aware of ourselves, even where this involves pain, becomes a precondition for relating to others in a new, creative manner. We noted earlier how already in Plotinus's account mystical ekstasis entailed a being-one with ourselves, a moment in which we act in the fullness of our being. In this moment of pure presence, bios and logos - what I do and what I say - are in harmony, and to the extent that I have achieved a 'unity of self', the pronoun 'you' that others may use as they refer to me finally has a concrete and unique reference point. And to the extent that the pronouns 'I' and 'you' eventually acquire meaning, the 'we' emerges as a reality. "Only humans who are capable of truly saying 'you' to one another can truly say 'we' together" (Buber quoted in Sölle: I65). In fact, Buber's later philosophy of the I-Thou does not reflect a departure from his earlier interest in mystical ecstasy but rather its explication (cf. Mendes-Flohr I978; Schwartz 2006). The relation to the Thou does not deny the ecstatic union experienced by the soul but examines this union in relation to its consequences.

\section{Politics and externalisation}

If ekstasis yields a surplus of freedom and thereby restores our ability to be 'present in relation', we need to ask how this ability could have been lost in the first place. The mystical vision is a revelation of possibilities which in a sense had been there previously, of opportunities which needed to be re-awoken. Ekstasis is thus the negation of a negation, the pushing aside of all that is preventing us from apprehending reality.

How do we get lost in the commotion of the world? And what is the role of society and politics in this process? A lucid analysis of these questions is provided by Plato's Republic, which in our reading implies a radical critique of politics. As our starting point we choose the passage at $404 \mathrm{c}-408 \mathrm{~b}$ (Plato 1987), where Plato discusses the education of the philosophers who are to rule the city. At one point, Plato introduces an interesting image, which describes a common individual and social pathology. He portrays a man living a life of idleness who enjoys fatty foods - "the luxury 
of Syracusan and Sicilian cooking" and "Attic confectionary" and too much alcohol, and who thereby fills his body "with gases and fluids, like a stagnant pool". As a result, his body will suffer and display symptoms of sickness. At this point an expert, a doctor, will be consulted. The doctor will look at the case and charge a fee in return for a diagnosis that confirms that our patient is indeed sick. The medical profession will have labels and names for the illness thus diagnosed - Plato mentions "flatulence" and "catarrh" as examples. From now on, our patient needs to look after his illness. He may require medication in order to manage symptoms; he may require regular visits to the doctor, who will in turn continue to attest that our patient is in need of medical care. Life may become a "lingering death" as our patient devotes much attention and energy to his affliction. We can easily imagine an entire industry of people who are all too eager to look after the patient by cosseting his illness because their very livelihoods depend on the patient requiring attention and treatment.

As Plato does not fail to note, however, there is an obvious and much less elaborate cure to the affliction: the patient must change his diet. He must change his habits, he must change his life, but this is exactly what he is not prepared to do. In frantic activity, he surrounds himself with theories, concepts, knowledge and people who will confirm to him that he is, indeed, ill. The point of the feverish activity is precisely to avoid a situation in which the patient would have to confront himself, his way of life. Elaborate systems of professions and services, often at the very heart of society, are created and entire lives are lived in order to escape the simple insight that we must change in order to live healthier, better lives. In the following reflections, we will refer to this pathology as 'externalisation'. Through externalisation, we locate the causes of our ailments, our alienation, our suffering outside of ourselves, thus exposing ourselves to the commotion of the world. Externalisation does not just involve individuals as individuals; rather, externalisation is systemic in that it relies on the recognition provided by the surrounding society. Thus, the objectification entailed in externalisation is a social phenomenon, because for externalisation to work effectively, recognition is crucial. 
In this image we gain a first inkling of society as a system of hideouts, where the members of society recognise and confirm each other's externalising practices (Shillabeer 2007). As they run away from themselves, they run towards each other. They objectify each other and thereby sanction the lies they tell about themselves. According to Plato, politics is crucial in this system because externalisation is the essence of politics. Politics is the creation of entire structures, of professions, of policies, of entire worlds that help us to not confront ourselves. Politics is externalisation, and as such it entails an infinite deferral: before I ever change myself, I can keep myself busy by changing the city, the state, the world. This is the reason also why for Socrates and Plato, philosophy and politics finds themselves in a relationship of tension, because philosophy, not unlike mysticism, is about self-knowledge - as embodied by Socrates, philosophy is about revealing and dissolving the lies we tell each other about ourselves.

Plato's Republic elaborates on this point not just in isolated images as in the example given above. The understanding of politics as externalisation is fundamental to the very structure of the dialogue. Initially, the Republic is a dialogue about justice, but then becomes, at a crucial point, a construction of a city "in words" and as a result the dialogue seems to deal with the political question of how to rule a city. However, in order to understand the purpose of the dialogue as a whole, it is important to understand why the characters in the dialogue felt it necessary to talk about cities in the first place. The transition occurs just after Socrates effectively won the argument against Thrasymachus, who had defended the position that "justice is simply what is in the interest of the stronger party". Socrates argues against Thrasymachus that "injustice never pays better than justice", and eventually prevails against his opponent, who accepts defeat: "This is your holiday treat [...], so enjoy it, Socrates" (354a). At this point, Socrates explains that he thought "the argument was over", and the book might have finished if indeed it was "only" about justice and the issues raised by Thrasymachus. Instead, the book continues because Glaucon is not satisfied with the ease with which Socrates defeated Thrasymachus and proceeds to 
restate the case for injustice, and he does so over several pages. Socrates is surprised that Glaucon, who had previously expressed his support for Socrates's position, is able to produce such an eloquent and powerful defence of the argument that it "pays off" to be unjust. Socrates's admiration for Glaucon's flexibility is ironic: "You must indeed have something divine about you, if you can put the case for injustice so strongly, and yet still believe that justice is better than injustice." (368a)

The problem that Socrates now has to deal with is not just an intellectual problem. In fact, the rational part of the discussion had been concluded with Thrasymachus's defeat. Glaucon's refusal, almost against his will, to accept the conclusions that had been reached, is the new driving force of the dialogue and the new problem that Socrates has to resolve. This is also the point at which Socrates, instead of addressing the condition of Glaucon's soul directly and hence personally, takes a detour and begins to talk about a city because, he explains, the city is "bigger" and hence it will be easier to see what is going on. Because the soul, especially Glaucon's soul, is too close to home, political themes are introduced as a deflection, allowing the discussion, which otherwise would have become very personal - and, for Glaucon, possibly uncomfortable - to continue. Glaucon and Adeimantus are perfectly happy to talk about how the city must change for justice to unfold; they would have been much less happy to talk about how they and their lives must change for justice to unfold in their souls.

The 'political' themes in Plato's dialogue are thus introduced as a deliberate externalisation in order to cater for the needs of Glaucon's and Adeimantus's souls. This 'gesture' is repeated at other key turning points in the dialogue. The first just city that Socrates outlines is what he calls the "healthy" city, in which citizens are content to live a simple life with few luxuries. Having completed the construction of the healthy city, Socrates proceeds to discuss the very nature of justice to be found in it, but this discussion comes to a sudden halt as Glaucon intervenes, accusing Socrates of having founded "a community of pigs" (372d). What Glaucon is implying here, unwillingly, is that he cannot see himself in the just city, without the luxuries he depends on. Put differently, he 
is not prepared to change so as to find his place in a city which he recognises as just. And so Socrates again proceeds to 'externalise' the problem, away from Glaucon, by discussing not the healthy but the "feverish" society, which will have all the luxuries that Glaucon requires, making the question of justice all the more complicated. The politics of the feverish society is thus an externalisation - a deferral, a deflection - of the fever in Glaucon's soul.

In the subsequent dialogue, Socrates needs to carefully re-introduce philosophical themes so as to allow Glaucon and Adeimantus to contemplate what it might mean to gradually remove themselves from their feverish societies and thus to personally face the question of justice. Throughout the text, philosophy is presented as the antidote to an existence in a cave-like society, whose members actively shun reality and kill those who draw attention to their condition. The escape from the cave is presented as an ascent and, more importantly, as a painful struggle as the soul must overcome the temporary blindness caused by the excessive brightness of the sun outside the cave. As in St John of the Cross's Dark Night of the Soul, the soul must endure a sudden deprivation a loss of sight - which in truth is the result of an influx of light which eventually reveals the full potential of the soul's ability to see. Accordingly, Plato emphasizes that the escape is more than a mere acquisition of knowledge. The escape or the 'turning around' (periagoge) as Plato describes it, is in effect the turning away from an 'old' life and the embracing of a 'new' life. The cave society had its very own codes of honour and glory, which distinguished the more keen-eyed prisoners who were best able "to remember the order of sequence among the passing shadows and so be best able to divine their future appearance" $(5 \mathrm{I} 6 \mathrm{c}-\mathrm{d})$, but clearly the released prisoner would not be able to return to the mode of life represented by the cave dwellers and their hierarchies: "[...] he would far rather be 'a serf in the house of some landless man', or indeed anything else in the world, than hold the opinions and live the life that they do."

Thus, the turning around amounts to an ekstasis, a stepping out, whereby society's practices and structures of externalisation lose their binding power. And in line with what we noted earlier - that the vision unfolds as a new 'presence in relation' - Socrates 
explains that the released prisoner is to return to the cave and be of service to those who dwell there. In other words, he must show "some care and responsibility for others" (520b). Of course, it is Glaucon who initially misses the point and takes the prisoner's vision as the foundation of a new code of honour, a new distinction, which would make him superior to the cave dwellers. It would be unfair, Glaucon protests, to ask the released prisoner to return to the cave because thereby he would be compelled to "live a poorer life than [he] might live". Just as he was unwilling to live in a society of pigs, Glaucon refuses to mix with the cave people. But now Socrates is in a position to remind Glaucon that the city they had constructed in words provided for the education of the philosophers, thus implying an obligation on the part of the philosophers to use their vision for the benefit of the whole community.

In Plato's analysis, therefore, externalisation is what ties us to the commotion of the world and prevents us from experiencing unity, including the unity of self. Through externalisation, we 'outsource' the responsibility we have for caring for our souls; we make ourselves dependent on a multitude of forces and interests over which we have very little control as we begin to live through the eyes of others. The false identity we gradually establish in our attempts to avoid confronting ourselves is confirmed through the recognition it receives from others, and vice versa. The result is a tacit 'contract' whereby the members of society sustain each other's lies not just through silence or by 'looking away' but by positively endorsing and encouraging the various illusions people spin around themselves. It would be a mistake to consider externalisation as a purely negative force because members of society will display a remarkable creativity in maintaining, sustaining, extending and embellishing the stories they consider their own. Externalisation is an active force, which requires its agents to actively engage with other people in order to find reassurance that their cover has not yet been blown. Gaps in existing stories have to be managed and filled with new stories, and real decisions with real consequences are taken in order to keep our stories and identities alive. The manner in which people relate to each other through the bonds they create through externalisation is marked by mutual dependency and mutual suspicion. To the extent that 
we 'outsource' ourselves, we remain 'absent in relation', as opposed to the interrelatedness that emerges from ekstasis, which restores our 'presence in relation'. The nakedness of ekstasis is thus directly opposed to the 'emperor's new clothes' that people wear in the societies built around practices of externalisation.

As the identities thus constructed inevitably remain fragile, extensive and costly efforts have to be invested into objectifying and ossifying them in structures and hierarchies. Therefore, even though members of society have to depend on each other for their stories to continue, their encounters and relations do not bring them closer together. On the contrary, the ultimate social effect of externalisation is differentiation and atomisation for the very purpose of the 'contract' is to allow members of society to be 'absent in relation'; ultimately, they remain aloof from the bonds of dependency that define their social identities. Externalisation thus generates both feverish social activity and atomisation. The 'contract' offers "human beings the illusion of an identity, of dignity, and of morality while making it easier for them to part with them." (Havel 20I0: I4) It also creates a culture of conformity, as everyone who dares to be different will attract the attention of those who rely on the predictability of the behaviour of others for maintaining their social status. Difference becomes problematic as it puts the existing narratives under pressure to adapt to a new, different situation, thus potentially exposing existing fissures and gaps. The dynamics of the situation will thus ensure that mimesis prevails whereby members confirm their complicity by copying each other. Mimesis ensures that externalisation becomes the very fabric of a particular kind of society, while politics is the means whereby these practices of externalisation struggle for permanency. In particular, the resulting objectification and rigidification must not be misunderstood as a political problem requiring a political solution. Politics, in Plato's analysis, is part of the problem, not its solution. The solution, in contrast, is the experience of $e k$ stasis: the restoration of openness, of 'being present in relation', and the new interrelatedness that unfolds from this presence.

In that we introduced these concepts through Plato's analysis of politics and society in the Republic, they remain theoretical notions without historical referent other than the Athenian polis 
that considered the teachings of Socrates, Plato's teacher, to be so dangerous and subversive that he was sentenced to death. In Plato's account, Socrates was not just an analyst of practices and structures of externalisation; he was also their victim, authenticating his analysis with his death. It is far beyond the scope of this essay to now trace the historical evolution of practices of externalisation in order to explore how 'politics', since the 'Greek discovery of politics' (Meier I990), could evolve into the hegemonic discourse and externalising practice that dominates modern societies today. However, it is worthwhile to look at the transition to modernity as a key moment in this evolution, and it is feasible to do so because it is precisely at that moment that Jean-Jacques Rousseau presents himself as the heir of Socrates' and Plato's ambitions (Orwin I998). Within the context of the questions raised in this essay, Rousseau appears as modernity's foremost theorist of externalisation as a social and individual pathology, and it is not accidental that he is also a key reference in the history of anarchism.

\section{Contra externalisation: Rousseau and anarchism}

Practices of externalisation generate societies in which members imprison themselves in the 'positions' in social and political hierarchies they create for themselves and others through mutual recognition. They sustain each other in a "second reality" (Voegelin I990: 49; Shillabeer 2007), where they can be 'absent in relation' and indefinitely defer the confrontation with self and reality. While much creativity can go into the creation of such second realities, their ultimate effect is constraining, and hence members of society may eventually recognise, with Rousseau, that "Man is born free, and everywhere he is in chains" (Rousseau I973c: I8I). Already in the First Discourse Rousseau offered an analysis of what it means to be 'absent in relation':

We no longer dare seem what we really are, but lie under a perpetual restraint; in the meantime the herd of men, which we call society, all act under the same circumstances exactly alike, unless very particular and powerful motives prevent them. Thus we never know with whom we have to deal; and even to know our friends 
we must wait for some critical and pressing occasion; that is, till it is too late; for it is on those very occasions that such knowledge is of use to us. (Rousseau I973a: 6)

While the First Discourse lamented how "we build our happiness on the opinion of others" (Rousseau I973a: 29), the Second Discourse develops these themes and attempts to explore 'inequality' as a consequence of externalisation. Rousseau's natural man, in contrast to Glaucon, would have been content in Plato's "healthy city" because of the natural limits to his desires:

I see him [natural man] satisfying his hunger at the first oak, and slaking his thirst at the first brook: finding his bed at the foot of the tree which afforded him a repast; and, with that, all his wants supplied. (Rousseau I973b: 52)

Natural men were strangers "to vanity, deference, esteem, and contempt" (Rousseau I973b: 76) because they "quietly await the impulses of nature, yield to them involuntarily, with more pleasure than ardour, and, their wants once satisfied, lose the desire" (Rousseau I973b: 78). Accordingly, natural man was "neither standing in need of his fellow-creatures nor having any desire to hurt them, and perhaps even not distinguishing them one from another" (Rousseau I973b: 79). The natural equality resulting from man's independence vanished as men "became accustomed [...] to making comparisons" (I973b: 89). As they live and work in greater proximity and contacts become more regular, they become conscious of each other's presence and thus "[e]ach one began to consider the rest, and to wish to be considered in turn; and thus a value came to be attached to public esteem. [...] this was the first step towards inequality [...]" (I973b: 90). Rousseau thus uses the term 'inequality' in its broadest sense as referring to a 'distinction of rank' primarily based on esteem. In Rousseau's usage of the term, inequality refers to the "taking into account of differences" (I973b: IIO-III), to an awareness of differences. While the political and economic inequalities that later theorists would focus on are inevitably the endpoint of this process of differentiation, Rousseau's 'inequality' has a much wider meaning. It refers to the process whereby men acquire a sense of self and others by comparing themselves with each other. To the extent that 
this process ossified into a system of 'ranks', with higher ranks reflecting more esteem than lower ranks, and to the extent that positions of rank were ultimately secured in relations of mutual recognition, it became

[...] the interest of men to appear what they really were not. To be and to seem became two totally different things; and from this distinction sprang insolent pomp and cheating trickery, with all the numerous vices that go in their train. On the other hand, free and independent as men were before, they were now, in consequence of a multiplicity of new wants, brought into subjection, as it were, to all nature, and particularly to one another; and each became in some degree a slave even in becoming the master of other men: if rich, they stood in need of the services of others; if poor, of their assistance; and even a middle condition did not enable them to do without one another. (1973 b: 95)

As a result, "man must now [...] have been perpetually employed in getting others to interest themselves in his lot, and in making them, apparently at least, if not really, find their advantage in promoting his own." This, in turn, rendered him "sly and artful in his behaviour to some, imperious and cruel to others [...]" (1973b: 95-96). From this process of comparing and measuring each other, there developed in man a "universal desire for reputation, honours, and advancement, which inflames us all [...]" (I973b: II2). The result is a feverish society, "an assembly of artificial men and factitious passions" (I973b: II5), in which this "desire of being talked about", "this unremitting rage of distinguishing ourselves", never gives us a moment's respite (I973 b: I I2). In this society, people are driven by "rivalry and competition on the one hand, and conflicting interests on the other, together with a secret desire on both of profiting at the expense of others" (I973b: 96):

Civilized man $[. .$.$] is always moving, sweating, toiling, and racking$ his brains to find still more laborious occupations: he goes on in drudgery to his last moment, and even seeks death to put himself in a position to live, or renounces life to acquire immortality. $\mathrm{He}$ pays his court to men in power, whom he hates, and to the wealthy, whom he despises; he stops at nothing to have the honour of ser- 
ving them; he is not ashamed to value himself on his own meanness and their protection; and, proud of his slavery, he speaks with disdain of those, who have not the honour of sharing it. (I973 b: I I 5 )

Our desires thereby were no longer subjected to their natural limits; on the contrary, as it was now our ambition to 'outdo' each other, our desires became limitless. Now "it appeared advantageous to any one man to have enough provisions for two" and more (1973b: 92).

For Rousseau, politics is the means whereby this new situation acquires a degree of permanency. Society and law "bound new fetters on the poor, and gave new powers to the rich; which irretrievably destroyed natural liberty, eternally fixed the law of property and inequality, converted clever usurpation into unalterable right, and, for the advantage of a few ambitious individuals, subjected all mankind to perpetual labour, slavery, and wretchedness" (I973 b: 99). The people surrendered to the new system as they "judged it not inexpedient to sacrifice one part of their freedom to ensure the rest; as a wounded man has his arm cut off to save the rest of his body." Thus, "all ran headlong to their chains, in hopes of securing their liberty [...]” (I973b: 99).

The strength of natural man was precisely that he never tried to outsource his power and ability because he had discovered "the advantage of having all our forces constantly at our disposal, of being always prepared for every event, and of carrying one's self, as it were, perpetually whole and entire about one." ( 1973 b: 54) In other words, natural man did not externalise and thus preserved what was for Rousseau the distinctly human characteristic of "free agency" (I973b: 60). In stark contrast, modern man lives in the opinions of others; indeed it is from their judgement that he derives "the consciousness of his own existence" (I973b: I I6):

[...] always asking others what we are, and never daring to ask ourselves, in the midst of so much philosophy, humanity, and civilization, and of such sublime codes of morality, we have nothing to show for ourselves but a frivolous and deceitful appearance, honour without virtue, reason without wisdom, and pleasure without happiness. (1973b: I I6) 
And precisely because our exteriors are deceitful appearance, we must rely on mutual recognition in order to supply them with the appearance of reality. Therefore, the ferocity of our "rage for distinction" is directly proportional to the chasm that exists between who we succeed in pretending to be and who we truly are.

Rousseau's analysis in the Second Discourse directly refers to the section in the Republic, referred to above, in which Socrates describes how we, with the help of the medical profession, cosset disease by giving an objective reality to ills of our own making (Rousseau I 973 b: 56-57). However, Rousseau is of interest to this essay not only because of his eloquent presentation of externalisation as the underlying dynamics of civilizational decline indeed of civilization as decline - but also because of his influence on radical reformist and revolutionary movements, particularly socialism and anarchism in their many variants. Throughout the I $9^{\text {th }}$ Century it was common to refer to Rousseau as the "master", "father" or "grandfather" of the socialists and other radical reformers of the time, who in turn were identified as the "disciples", “sons," or "grandsons" of Rousseau (Noland I967: 33). In I 85 I, Proudhon acknowledged that the "authority" of Rousseau had "ruled us for almost a century" (Noland I967: 35; Crowder I99I: I6). For a thinker like Proudhon, however, "authority" is an ambiguous notion and indeed while he could call Rousseau a "great innovator" and "the apostle of liberty and equality", he could also occasionally express sentiments of revulsion and disgust: "Never did a man unite to such a degree intellectual pride, aridity of soul, baseness of tastes, depravity of habits, ingratitude of heart [...]" (quoted in Noland: 36-37). Godwin is generally more sympathetic towards Rousseau and acknowledged him as a major influence on the Enquiry Concerning Political Justice, admitting that he "frequently quoted Rousseau in the course of this work." However, in the very same footnote, he found space to express his reservations: "Rousseau, notwithstanding his great genius, was full of weakness and prejudice" (Godwin I993: 273).

The relation between the anarchists and Rousseau is complex as different anarchists adopt different positions towards Rousseau. In fact, there is often little consistency in the treatment Rousseau receives in the writings even of individual anarchists. Godwin and 
Proudhon are very much aware of his writings, and they discuss them explicitly in their works in many places. Sometimes the engagement with Rousseau amounts to positive influence, sometimes to negative reaction - with the former tending to predominate in Godwin, and the latter in Proudhon (Crowder: I7-I8). Tolstoy idolised Rousseau in his youth and adopted similar views to his on education, compassion, and religion, even if he was critical of the notion of a 'general will' (Christoyannopoulos 20I9). Kropotkin admired him for having been an eloquent defender of equality and human rights and for having thereby exerted a positive influence on the French Revolution (Crowder: I9). Bakunin too confirmed Rousseau's influence on the Revolution but ultimately judges this influence to be malign. Still, at another time in his life, he declared that "in his faith in the eventual triumph of mankind over priests and tyrants he is at one with the 'immortal Rousseau'” (Crowder: I9).

Paul McLaughlin suggested that, among all the philosophes, Rousseau "may have had the greatest influence on the development of anarchism" (McLaughlin 2007: 105). There are many reasons why the anarchists would have felt drawn to Rousseau, who was arguably the most radical thinker of his age. First, Rousseau's notion of a realm of freedom as "a 'natural' order outside the artificiality of the state" (Crowder: 23) must have appealed to his anarchist readers. It is correct, of course, that this vision of stateless freedom also posed a problem in that it seemed to suggest that it was the rise of society itself that disrupted and ultimately irretrievably destroyed the possibility of man living at peace with himself, virtuous and free, and without government. Godwin, for example, was critical of Rousseau's suggestion that statelessness would not be possible under modern conditions. Still, he was too endeared by the vision itself and, instead of abandoning it, simply reversed Rousseau's scheme of history. The happy, virtuous, free anarchy was not a memory of the past, but a prospect for the future following the abolition of government and law.

Second, the text that caused the greatest problems for Rousseau's anarchist readers was The Social Contract, because here Rousseau seems to subscribe to what was arguably the most influential justification of the state at the time, the social contract 
tradition. Even Godwin, who felt so close to the sentiments and analyses provided in the Second Discourse and in Emile, noted that in Rousseau's political writings, "the unrivalled superiority of his genius appears to desert him" (Godwin I993: 273). Moreover, a superficial reading of Rousseau's contract may give the impression that he, too, subscribed to the classic argument of the contractarians that freedom is pre-social and must be constrained by government in order to allow men to coexist in society. This critique, put forward also by Proudhon and Bakunin, fails to appreciate the subtlety of Rousseau's construction, which upon closer inspection can also be read as proposing precisely the kind of self-governing community that the anarchists were debating. After all, The Social Contract did not create a state separate from those it governed. In fact, the core principle of Rousseau's vision is the inviolability of moral self-direction as the key feature of freedom. It is in The Social Contract that Rousseau describes moral self-direction as the very essence of "being a man" (Rousseau I973c: I 86), and it is not impossible therefore that this work least loved by anarchists - is the very source of what is perhaps the most fundamental of their premises. Accordingly, at the very start of the Social Contract, Rousseau explained that the work was meant "to inquire if, in the civil order, there can be any sure and legitimate rule of administration, men being taken as they are and laws as they might be," thus raising the key anarchist question as to whether government as such - not what form, or how much - is legitimate (McLaughlin 2007: I06).

Third, anarchists would also accept the basic tenets of Rousseau's analysis of modern society as a complex web of dependencies in which both the subservient and the dominant had become alienated from their true moral nature. The introduction of governments makes this structure permanent, and the resulting moral decline is pervasive to such an extent that mere reform is insufficient for freedom and virtue to be attained. A total transformation of society is required.

Rousseau had gone further than any other thinker in advocating two related positions: (i) freedom and agency, the defining features of human existence, are to be understood as moral self-direction (cf. Spaan 20I I), and (ii) modern, civilized society is destructive of 
moral self-direction because externalisation, which is the opposite of self-direction, is its very fabric. It is on these two fundamental positions that Rousseau's and the anarchists' outlooks converge. Thus, anarchists, too, can be read as theorists of externalisation. Godwin, for example, noted that "he that is not accustomed, exclusively to act upon the dictates of his own understanding, must fall infinitely short of that energy and simplicity of which our nature is capable." (Godwin I993: 306) Looking specifically at the politics of national assemblies, he observes how men inescapably end up losing the autonomy of their decision-making:

Every man looks forward to the effects which the opinions he avows will produce on his success. Every man connects himself with some sect or party. The activity of his thought is shackled at every turn by the fear that his associates may disclaim him. (Godwin I993: 307)

Indeed, "men who act under the name of society, are deprived of that activity and energy which may belong to them in their individual character. They have a multitude of followers to draw after them, whose humours they must consult, and to whose slowness of apprehension they must accommodate themselves." (Godwin I993: 308) Thus, the politics of government, where the need to take binding decisions requires the imposition of a "fictitious unanimity," ultimately leads men to abandon the principle of self-direction and to pursue their self-interests in competition with others by making their decisions and actions dependent on the strategic requirements of the situation. Thus, before laws can be introduced, "numerous amendments have [to be made] to suit the corrupt interest of imperious pretenders" (Godwin I993: 307). The result is a derailment, a loss of openness, a collective and individual inability to detach ourselves from the commotion of the world - to use Buber's term - and to look beyond our selfinterests and the opinions of others. In other words, we become unable to 'apperceive':

The genuine and wholesome state of mind is, to be unloosed from shackles, and to expand every fibre of its frame according to the independent and individual impressions of truth upon that mind. How great would be the progress of intellectual improvement, if 
men were unfettered by the prejudices of education, unseduced by the influence of a corrupt state of society, and accustomed to yield without fear to the guidance of truth, however unexplored might be the regions and unexpected the conclusions to which she conducted us? (Godwin 1993: 306-307)

\section{Mysticism, anarchism and anti-politics}

Mystical ekstasis pierces through the 'cloud of unknowing', the fog of externalisation, and thereby restores our openness to reality, our being 'present in relation'. The analogy between mysticism and anarchism is based on their convergence on a critique of externalisation, which is considered as the pathology - operating at an individual and social level - which undermines moral selfdirection as the essence of our humanity. Thus, the modern state, as the ultimate manifestation of externalisation, de-humanises.

The thinker who brings these notions of mysticism, anarchism and the critique of politics together most clearly is, of course, Gustav Landauer. The influence of Meister Eckhart, the German mystic (c.I260-c.I328), on Landauer is well documented (e.g. Hinz 2000; Sauerland I999). During his imprisonment in I 899/I900, Landauer spent considerable time translating some of Eckhart's sermons; these translations were later published as a book (Landauer 1903). Joachim Willems suggested that since the encounter with Eckhart, mysticism assumed a systemic role in Landauer's philosophical and political work, signifying a "decisive turn" in his thought (Willems 200I: I2). How mysticism was absorbed in Landauer's political thinking is evident as early as I90I in his essay Anarchistische Gedanken über Anarchismus [Anarchic Thoughts on Anarchism] (Landauer 20IOb), where he argues that the anarchic society can only be achieved through a mystic re-birth, an "inward colonization": "Those whom I call true anarchists no longer deceive themselves; they have been able to remold themselves through the experience of a deep existential crisis; they can act in the way which their most secret nature demands." (Landauer 20Iob: 87) The anarchists, he continues, "will not kill anyone except themselves - in the mystical sense, in order to be reborn after having descended into the depths of their souls." 
(88) It was not enough to reject conditions and institutions: "we have to reject ourselves" in order "to become one with the world in a mystical union."

What these men will be able to bring to the world will be so extraordinary that it will seem to have come from a world altogether unknown. Whoever brings the lost world in himself to life - to individual life - and whoever feels like a true part of the world and not as a stranger: he will be the one who arrives not knowing where from, and who leaves not knowing where to. To him the world will be what he is to himself. Men such as this will live with each other in solidarity - as men who belong together. This will be anarchy. (89)

Landauer's path towards the anarchic community is via Absonderung, separation, a concept informed by Meister Eckhart's Abgeschiedenheit. (Hoppen 2017, 2018) Eckhart's concept refers to the detachment that prepares and effectuates the mystical ekstasis, the breaking through the commotion of the world. Landauer's separation wants to capture the same movement, but highlights its importance in enabling individuals to live communally, away from the influences of authority, state and, indeed, politics:

And the state exists to create order and the possibility to continue living amid all this spiritless nonsense, confusion, hardship and degeneracy. The state, with its schools, churches, courts, prisons, workhouses, the state with its army and its police; the state with its soldiers, officials and prostitutes. Where there is no spirit and no inner compulsion, there is external force, regimentation, the state. Where spirit is, there is society. Where unspirit is, there is the state. The state is the surrogate for spirit.

The state, which is "nothing", a "false illusion", conceals this nothingness and, disguised as "nation", becomes the "psychic equivalent to the intoxicating alcoholic spirits that have become the habitual poison of men living today". (Landauer I9II) Since the late I890s, Landauer described himself as an "anti-politician": "I was never politically, only anti-politically engaged" (cited in Wolf 20I0: 26). Anarchists, he wrote, "have no political beliefs - we have beliefs against politics" (Landauer 20 I0a: 79). Landauer's anti-politics is commonly understood as a rejection 
of formal politics, but the concept goes much further - what is at stake in Landauer's symbolism is a 'stepping out' of politics altogether. Like ekstasis, anti-politics is the negation of a negation - and this negation cannot be achieved from within politics. Political change only perpetuates and reinforces the hegemony of the discourse and practice of politics. As politics presents itself as the solution to the problems it creates, it further strengthens its grip on life and further normalises externalisation: "politics is inherently antonymous to community" (Hoppen 20I8: 86). Anti-politics, in Landauer's understanding, is therefore defined in opposition to politics only in name; its reality is sui generis, referring to the evocation and unfolding of a community whose members are 'present in relation'. The members of the true community, Landauer explains, will not aspire to order the world externally through politics, but they will find the world within themselves and become the world (Landauer 20IOc: IOO).

In the context of this essay, Landauer represents the oddity of an actually existing 'ideal type': his work, as an author and activist, exemplifies precisely the analogies between mysticism and anarchism explored previously, including the rejection of politics as encrusted externalisation. The historical singularity of this example, however, should not distract from the more general point we wished to develop in this essay: the orientation away from externalisation is a key feature of anarchist thought and practice, and it is in this orientation that the analogy between anarchism and mysticism is rooted, giving them analogous roles in political theory and theology respectively. A community in which members are 'present in relation' is anarchic. Anarchy thus does not refer to lawlessness and chaos, but to a particular kind of relationality, which springs forth from the 'stepping out', ekstasis, of the commotion of the world. Moreover, even if articulated in secular or atheist terms, and to the extent that it advocates the overcoming of externalising practices, anarchism has at its core a spiritual concern.

If we develop the analogy between mysticism and anarchism further, however, we may have to acknowledge that there are distinct limits to our ability to create such anarchic communities by design. Mystics emphasise that the stepping out of ekstasis cannot 
be willed or forced. In particular, conventional politics is not a solution to the problem; on the contrary, as we noted, externalisation is the very essence of politics. It would be misleading and ultimately self-defeating, therefore, to present anarchism as a political philosophy - just as it is impossible to establish mysticism as a religious institution. These reflections leave us with the profound question of how indeed we can 'body forth' communities in which we can be 'present in relation'. Many anarchists, including Landauer, were and are aware of the problem. It was a "crucial fallacy," he noted, to think "that one can - or must - bring anarchism to the world." Those "who want "to bring freedom to the world' [...] are tyrants, not anarchists." Indeed, “[a]narchy is not a matter of the future; it is a matter of the present. It is not a matter of making demands; it is a matter of how one lives." (Landauer 20Iob: 87). These notions are not too far away from Occupy's "We make the path by walking" (taken from Antonio Machado's poem Caminante no hay camino, I9I2), and not unlike Occupy, anarchists may need to ponder the meaning and possibility of an ekstasis from politics.

\section{References}

Bloch, E. (1972) Atheism in Christianity. New York: Herder \& Herder.

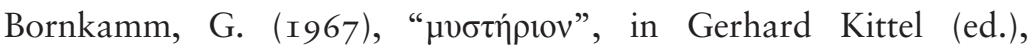
Theological Dictionary of the New Testament, Vol.IV. Grand Rapids, MI: Eerdmans, pp. 802-828.

Bouyer, L. (I98I) "Mysticism: an essay on the history of the word," in Richard Woods (ed.), Understanding Mysticism. London: Athlone Press, pp. 42-55.

Buber, M. (I958) I and Thou, $2^{\text {nd }}$ ed., transl. by Ronald Gregor Smith. Edinburgh: T\&T Clark.

Buber, M. (1967) “Autobiographical Fragments," in Paul Arthur Schilpp and Maurice Friedman (eds) The Philosophy of Martin Buber. London: Cambridge University Press, pp. 3-39.

Buber, M. (I996) "Introduction: Ecstasy and Confession”, in Buber, Ecstatic Confessions: The Heart of Mysticism, ed. by Paul MendesFlohr. Syracuse: Syracuse University Press, pp. I-I I. 
Christoyannopoulos, A. (2020). Tolstoy's Political Thought: Christian Anarcho-Pacifist Iconoclasm Then and Now. Abingdon: Routledge.

Critchley, S. (2009) "Mystical Anarchism," in Critical Horizons: A Journal of Philosophy and Social Theory, Vo. Io, No. 2, pp. 272-306.

Crowder, C. (I99I) Classical Anarchism: The Political Thought of Godwin, Proudhon, Bakunin, and Kropotkin. Oxford: Clarendon Press.

Derrida, J. (I992a) "How to Avoid Speaking: Denials", transl. Ken Frieden, in H. Coward and T. Foshay (eds) Derrida and Negative Theology. Albany: SUNY Press, pp. 73-142.

Derrida, J. (I992b), "Post-Scriptum: Aporias, Ways and Voices", transl. John P. Leavey Jr., in H. Coward and T. Foshay (eds) Derrida and Negative Theology. Albany: SUNY Press, pp. 283-323.

Dodds, E.R. (1965) Pagan and Christian in an Age of Anxiety: Some Aspects of Religious Experience from Marcus Aurelius to Constantine. Cambridge: Cambridge University Press.

Ellwood, R.S. (I999) Mysticism and Religion, $2^{\text {nd }}$ ed. New York: Seven Bridges Press.

Fox, M. (I98I) "Meister Eckhart and Karl Marx: The Mystic as Political Theologian," in Richard Woods (ed.), Understanding Mysticism. London: Athlone Press, pp. 54I-563.

Gellman, J. (200I) Mystical Experiences of God: A Philosophical Inquiry. Aldershot: Ashgate.

Godwin, W. (1993) An Enquiry Concerning Political Justice, and its influence on General Virtue and Happiness, Political and Philosophical Writings of William Godwin Vol. 3, ed. by Mark Philp. London: Pickering.

Gregory, J. (1999) The Neoplatonists: A Reader, $2^{\text {nd }}$ ed. London: Routledge.

Hadot, P. (1998) Plotinus or The Simplicity of Vision. Chicago: The University of Chicago Press. 
Havel, V. (20I0) "The Power of the Powerless," in Vaclav Havel et al. The Power of the Powerless: Citizens against the State in Centraleastern Europe. New York: Routledge, pp. Io-59.

Hinz, T. (2000) Mystik und Anarchie: Meister Eckhart und seine Bedeutung im Denken Gustav Landauers. Berlin: Karin Kramer Verlag.

Hoppen, F. (20I7) "A Reflection on Mystical Anarchism in the Works of Gustav Landauer and Eric Voegelin," in A. Christoyannopoulos and M.S. Adams (eds) Essays in Anarchism and Religion: Volume I. Stockholm: Stockholm University Press, pp. 198-237.

Hoppen, F. (2018) Putting politics in its place: Philosophies and Practices of Presence in the works of Gustav Landauer, Eric Voegelin, Simone Weil and Václav Havel. Unpublished $\mathrm{PhD}$ Dissertation, University of Kent.

James, W. (1985) The Varieties of Religious Experience. New York: Penguin.

Landauer, G. (I903) Meister Eckharts Mystische Schriften. In Unsere Sprache Übertragen Von Gustav Landauer. Berlin: Schnabel.

Landauer, G. (I9II) "Call to Socialism", available at the online Anarchist Library, https://theanarchistlibrary.org/library/ gustav-landauer-call-to-socialism.

Landauer, G. (2010a) “A Few Words on Anarchism”, in Gustav Landauer, Revolution and Other Writings: a Political Reader, transl. and ed. by Gabriel Kuhn. Oakland, CA: PM Press, pp. 79-83.

Landauer, G. (20Iob) "Anarchic Thoughts on Anarchism," in Gustav Landauer, Revolution and Other Writings: a Political Reader, transl. and ed. by Gabriel Kuhn. Oakland, CA: PM Press, pp. 84-9I

Landauer, G. (20IOc) “Through Separation to Community," in Gustav Landauer, Revolution and Other Writings: a Political Reader, transl. and ed. by Gabriel Kuhn. Oakland, CA: PM Press, pp. 94-Io8

Landauer, G. (20I I) Skepsis und Mystik: Versuche im Anschluss an Mauthners Sprachkritik, ed. by Siegbert Wolf. Bodenburg: Verlag Edition AV. 
Maréchal, J. (1927) Studies in the Psychology of the Mystics (transl. Algar Thorold). London: Burns Oates and Washbourne Ltd.

McGinn, B. (1989) "Love, Knowledge and Unio Mystica in the Western Christian Tradition," in Moshe Idel and Bernard McGinn (eds) Mystical Union and Monotheistic Faith: An Ecumenical Dialogue. New York: Macmillan, pp. 59-86.

McGinn, B. (1997) The Foundations of Mysticism: Origins to the Fifth Century. New York: Crossroads.

McLaughlin, P. (2007) Anarchism and Authority: a Philosophical Introduction to Classical Anarchism. Aldershot: Ashgate.

Meier, C. (I990) The Greek Discovery of Politics (transl. by David McClintock). Cambridge, MA: Harvard University Press.

Mendes-Flohr, P. (1978) Von der Mystik zum Dialog: Martin Bubers geistige Entwicklung bis bin zu "Ich und Du" (transl. Dafna A. Kries). Königstein/Ts.: Jüdischer Verlag.

Mendes-Flohr, P. (I996) "Editor's Introduction," in Martin Buber, Ecstatic Confessions: The Heart of Mysticism, ed. by Paul MendesFlohr. Syracuse: Syracuse University Press, xiii-xxx.

Moore, D.J. (1996) Martin Buber: Prophet of Religious Secularism. $2^{\text {nd }}$ ed. Bronx, NY: Fordham University Press.

Noland, A. (1967) "Proudhon and Rousseau," in Journal of the History of Ideas 28(I): 33-54.

Orwin, C. (1998) “Rousseau's Socratism," in The Journal of Politics $60(\mathrm{I}): \mathrm{I} 74-87$.

Plato (I987) The Republic, transl. Desmond Lee. $2^{\text {nd }}$ ed. New York: Penguin.

Plotinus (I969) The Enneads, $4^{\text {th }}$ edn, trans. S. Mackenna. London: Faber \& Faber.

Pseudo-Dionysius (1987a) The Divine Names, trans. Colm Luibheid, in Pseudo-Dionysius, The Complete Works. Mahwah, NJ: Paulist Press, pp. 47-I3I.

Pseudo-Dionysius(1987b)The CelestialHierarchy,trans.ColmLuibheid, inPseudo-Dionysius, The Complete Works.Mahwah,NJ:PaulistPress, pp. I 43-259. 
Rousseau, J.J. (I973a) A Discourse on the Moral Effects of the Arts and Sciences, transl. G.D.H. Cole, in Jean-Jacques Rousseau, The Social Contract and Discourses. London: Dent and Sons, pp. I-30.

Rousseau, J.J. (I973b) A Discourse on the Origin of Inequality, trans. G.D.H. Cole, in Jean-Jacques Rousseau, The Social Contract and Discourses. London: Dent and Sons, pp. 3 I-I 26.

Rousseau, J.J. (r973c) The Social Contract, trans. G.D.H. Cole, in Jean-Jacques Rousseau, The Social Contract and Discourses. London: Dent and Sons, pp. I79-309.

Sauerland, K. (I999) “Mystisches Denken zur Jahrhundertwende: der junge Lukács, Mauthner, Landauer, Buber, Wittgenstein und der junge Broch," in Marijan Bobinac (ed.) Literatur im Wandel: Festschrift für Viktor Žmegač. pp. I75-190.

Schwartz, Y. (2006), "Martin Buber and Gustav Landauer: The Politicization of the Mystical", in Michael Zank (ed.) Martin Buber: Neue Perspektiven/New Perspectives. Tübingen: Mohr Siebeck, pp. 205-2I9.

Shillabeer, J. (2007) Self-Knowledge, Immunity and Conversion: Doderer, Musil and Voegelin on 'Second Realities' and the Soul's Struggle for Truth. Unpublished PhD Dissertation, University of Kent.

Smart, N. (1965) "Interpretation and Mystical Experience," in Religious Studies, Vol. I, No. I, pp. 75-87.

Sólle, D. (200I) The Silent Cry: Mysticism and Resistance. Minneapolis: Fortress Press.

Spaan, C. (2OI I) Anarchism as a Form of Government. Unpublished PhD Dissertation, University of Kent.

Turner, D. (I995) Eros and Allegory: Medieval Exegesis of the Song of Songs. Kalamazzo, MA: Cistercian Publications.

Underhill, E. (2002) Mysticism: A Study in the Nature and Development of Spiritual Consciousness. Mineola, NY: Dover.

Voegelin, E. (I990) “On Debate and Existence," in Eric Voegelin, Published Essays I 966-I985, The Collected Works of Eric Voegelin Volume I2, ed. by Ellis Sandoz. Baton Rouge, LO: Louisiana State University Press, pp. 36-5I. 
254 Essays in Anarchism and Religion: Volume III

Willems, J. (200I) Religiöser Gehalt des Anarchismus und anarchistischer Gehalt der Religion? Die jüdisch-christlich-atheistische Mystik Gustav Landauers zwischen Meister Eckhart and Martin Buber. Albeck bei Ulm: Verlag Ulmer Manuskripte.

Wolf, S. (20II), "Einleitung", in Gustav Landauer, Skepsis und Mystik: Versuche im Anschluss an Mauthners Sprachkritik, ed. by Siegbert Wolf. Bodenburg: Verlag Edition AV. 